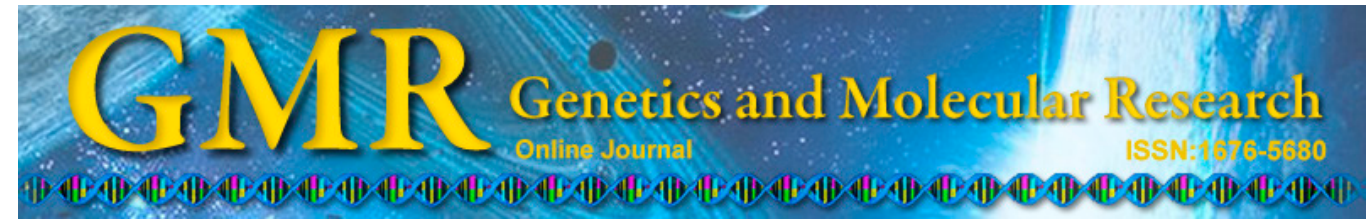

\title{
Development of novel and polymorphic microsatellite DNA loci from Haliotis ovina
}

\author{
Z.B. Li ${ }^{1,2}$, X.J. Tian ${ }^{1,2}$, J.B. Shangguan ${ }^{1,2}$, Y.Y. Cao ${ }^{1,2}$, G.L. Zhang ${ }^{1,2}$ and \\ L.N. Chen ${ }^{1,2}$
}

${ }^{1}$ Fisheries College, Jimei University, Xiamen, China ${ }^{2}$ Fujian Provincial Key Laboratory of Marine Fishery Resources and Eco-Environment, Xiamen, China

Corresponding author: Z.B. Li

E-mail: lizhongbao@jmu.edu.cn

Genet. Mol. Res. 14 (1): 525-528 (2015)

Received January 3, 2014

Accepted March 24, 2014

Published January 26, 2015

DOI http://dx.doi.org/10.4238/2015.January.26.6

\begin{abstract}
Twelve microsatellite loci were developed from Haliotis ovina by the magnetic bead hybridization method. Genetic variability was assessed using 30 individuals from 3 wild populations. The number of alleles per locus ranged from 2 to 5 , and the polymorphism information content ranged from 0.1228 to 0.6542 . Observed and expected heterozygosities ranged from 0.0000 to 0.7778 and 0.1288 to 0.6310 , respectively. These loci should provide useful information for genetic studies such as genetic diversity, pedigree analysis, construction of genetic linkage maps, and marker-assisted selection breeding in H. ovina.
\end{abstract}

Key words: Genetic markers; Haliotis ovina; Microsatellite markers 


\section{INTRODUCTION}

The abalone is a marine gastropod and widely distributed along the coastal waters of tropical and temperate regions (Geiger, 1999). Among 20 commercially important abalone (Jarayabhand and Paphavasit, 1996), Haliotis ovina, which is also primarily distributed in tropical areas, has high economic importance with regard to the fishing and farming industries. Although $H$. ovina is not a main target species for aquaculture in China, the genetic information of $H$. ovina is essential because of the rapid decline of China's natural resources due to overexploitation and pollution. Thus, further conservation strategies and recovery plans require basic genetic information on $H$. ovina.

Microsatellite analysis is an effective molecular tool and has a variety of applications. Until now, microsatellite markers in H. rubra (Huang and Hanna, 1998; Evans et al., 2000), $H$. asinina (Selvamani et al., 2000), H. discus hannai (Li et al., 2002), H. kamtschatkana (Miller et al., 2001), and H. discus discus (Sekino and Hara, 2001) have been reported. Also, microsatellite markers have been applied to analyze the genetic background of H. rubra (Evans et al., 2004; Li et al., 2006), H. conicorpora (Li et al., 2006), H. discus hannai (Li et al., 2003, 2004), H. midae (Evans et al., 2004), and H. asinina (Selvamani et al., 2001). To our knowledge, the genetic study of H. ovina has been limited, to date (Klinbunga et al., 2003; Li, 2006, 2009; Li et al., 2008).

\section{MATERIAL AND METHODS}

One wild individual from the Yingzhou population was used for simple sequence repeat (SSR) primer screening. Genomic DNA was extracted from the foot muscle using the CTAB method and examined by agarose gel electrophoresis (1\%) and ultraviolet spectrophotometer. The sample was then digested with MboI (Fermentas, Canada) for $3 \mathrm{~h}$ $\left(37^{\circ} \mathrm{C}\right)$. Subsequently, MboI adapter1 (5'-GATCGTCGACGGTACCGAATTCT-3') and MboI adapter2 (5'-GTCAAGAATTCGGTACCGTCGAC-3') were ligated to the digested products using T4 DNA ligase. The ligated product was hybridized with biotin-labeled SSR probes $\left[(\mathrm{GT})_{15}\right.$ and $\left.(\mathrm{CT})_{15}\right]$, and the hybrid mixture was incubated with magnetic beads coated with streptavidin. The recovered DNA fragments were amplified using MboI primer (5'-GTCAAGAATTCGGTACCGTCGAC-3') and the polymerase chain reaction (PCR) products were purified by GenCleanPCR (GENEray, Shanghai, China) to remove the extra dNTPs and adaptors. The purified products $(4.5 \mu \mathrm{L})$ were ligated to pMD19-T $(0.5 \mu \mathrm{L})$ and then transformed into Escherichia coli. The transformants were selected on ampicillin plates.

A total of 576 colonies were chosen to mix with $60 \mu \mathrm{L} \mathrm{LB}$ liquid medium and then shake cultured for $3 \mathrm{~h}\left(37^{\circ} \mathrm{C}, 140 \mathrm{rpm}\right)$. DNA fragments $>500 \mathrm{bp}$ were selected for sequencing by the Beijing Liuhehuada Company. A total of 40 pairs of primers were designed using Primer Premier 5.0 (Clarke and Gorley, 2001). Thirty individuals from Yingzhou (109 51'9"E; $\left.18^{\circ} 22^{\prime} 37^{\prime \prime N}\right)$, Anyou (109 $33^{\prime} 14^{\prime \prime E}$; $\left.18^{\circ} 12^{\prime} 11^{\prime \prime N}\right)$, and Yalong Wan $\left(109^{\circ} 38^{\prime} 36^{\prime \prime E} ; 18^{\circ} 11^{\prime} 13^{\prime \prime N}\right)$ were then used to analyze polymorphisms of the loci.

The PCR amplification conditions consisted of an initial denaturation at $94^{\circ} \mathrm{C}$ for 5 min; 30 cycles at $94^{\circ} \mathrm{C}$ for $45 \mathrm{~s}$, annealing temperature (Table 1) for $45 \mathrm{~s}$, and an extension at $72^{\circ} \mathrm{C}$ for $1 \mathrm{~min}$; and a final extension at $72^{\circ} \mathrm{C}$ for $10 \mathrm{~min}$. The PCR products were electrophoresed via Sequi-Gen Sequencing Cell (BIO-RAD), and the $H_{\mathrm{O}}, H_{\mathrm{E}}, N_{\mathrm{A}}$, and PIC (polymorphism information content) were calculated using the GENEPOP 4.0 software (Rousset, 2010) and CERVUS 3.0 (Gao and $\mathrm{Wu}, 2005$ ) (Table 1). 


\section{RESULTS AND DISCUSSION}

Twelve polymorphic microsatellite primers were developed. The number of alleles per locus ranged from 2 to 5 , and the PIC ranged from 0.1228 to 0.6542 . The $H_{\mathrm{O}}$ and $H_{\mathrm{E}}$ ranged from 0.0000 to 0.7778 and 0.1288 to 0.6310 , respectively (Table 1). MICRO-CHECKER (Van Oosterhout et al., 2004) was applied to check microsatellite data. Genotyping error was not detected among the loci.

\begin{tabular}{|c|c|c|c|c|c|c|c|c|c|}
\hline Locus ID & Primer sequence $\left(5^{\prime}-3^{\prime}\right)$ & $N_{\mathrm{A}}$ & Repeat motif & $\begin{array}{l}\text { Allele size } \\
\text { (bp) }\end{array}$ & PIC & $H_{\mathrm{O}}$ & $H_{\mathrm{E}}$ & $\begin{array}{l}\mathrm{Ta} \\
\left({ }^{\circ} \mathrm{C}\right)\end{array}$ & $\begin{array}{l}\text { GenBank } \\
\text { accession No. }\end{array}$ \\
\hline YB4 & $\begin{array}{l}\text { F: ACACGAACCAAGATTAGAGG } \\
\text { R: TGAGAGAGGAGAACAAGGAA }\end{array}$ & 3 & $(\mathrm{TC})_{5}(\mathrm{CA})_{3} \mathrm{~N}_{2}(\mathrm{CA})_{20}$ & $190-225$ & 0.2763 & 0.0741 & 0.1426 & 49 & JN561131 \\
\hline YB14 & $\begin{array}{l}\text { F: TGGTCGCTGGAGAATCGT } \\
\text { R: TGCCGTGACACTGGAAAG }\end{array}$ & 5 & $(\mathrm{CTCA})_{3}(\mathrm{CA})_{2}(\mathrm{CTCA})$ & $180-250$ & 0.5395 & 0.5517 & 0.5638 & 45 & JN561132 \\
\hline YB15 & $\begin{array}{l}\text { F: GACGACACCGATAGGAGA } \\
\text { R: AAGAGGGACAGAGGCTTG }\end{array}$ & 5 & $(\mathrm{CA})_{26} \mathrm{CG}(\mathrm{CT})_{20}$ & $180-210$ & 0.4013 & 0.1852 & 0.3026 & 40 & JN561133 \\
\hline YB22 & $\begin{array}{l}\text { F: GGAACTTCAACATCCCCT } \\
\text { R: TTCAAACTTAGAACCCGC }\end{array}$ & 2 & $(\mathrm{GA})_{18}$ & $275-285$ & 0.5169 & 0.0769 & 0.5077 & 46 & JN561134 \\
\hline YB23 & $\begin{array}{l}\text { F: ATTTCCCCGAGTACACCATACG } \\
\text { R: TAGGACTTCAGATTGACGAGCG }\end{array}$ & 3 & $(\mathrm{GA})_{9} \mathrm{~N}_{2}(\mathrm{GA})_{19}$ & $235-285$ & 0.3361 & 0.1154 & 0.1802 & 55 & JN561135 \\
\hline YB48 & $\begin{array}{l}\text { F: ACTGTGTCTGAGTGGGGTATT } \\
\text { R: AAGTTTTTTTGTGAGTGAGCA }\end{array}$ & 4 & $(\mathrm{CA})_{22}$ & $160-175$ & 0.6184 & 0.7778 & 0.6101 & 44 & JN561136 \\
\hline YB55 & $\begin{array}{l}\text { F: TTGCCTATGTCAGCACAGTTC } \\
\text { R: AAGCAATCAACCAATCACCTG }\end{array}$ & 5 & $(\mathrm{GT})_{17}$ & $185-210$ & 0.5360 & 0.5357 & 0.5143 & 46 & JN561137 \\
\hline YB68 & $\begin{array}{l}\text { F: TGTGCTGTGCTATAAATGTCAC } \\
\text { R: TTGTCTTTGTATCGGAGGTTG }\end{array}$ & 3 & $(\mathrm{CA})_{18}$ & $200-200$ & 0.5936 & 0.4706 & 0.5419 & 46 & JN561138 \\
\hline YB70 & $\begin{array}{l}\text { F: TCCATTTTGTGATGACTCC } \\
\text { R: GACGACACTTTGTTGCTCT }\end{array}$ & 3 & $(\mathrm{CA})_{4} \mathrm{~N}_{2}(\mathrm{CA})_{21}$ & $160-200$ & 0.1228 & 0.0667 & 0.1288 & 45 & JN561139 \\
\hline YB77 & $\begin{array}{l}\text { F: GATGTAGCAAAATGTAACCCC } \\
\text { R: ATCCCCTCGCAAACCCAG }\end{array}$ & 3 & $(\mathrm{GA})_{47}$ & $250-270$ & 0.6542 & 0.6000 & 0.6310 & 46.5 & JN561140 \\
\hline YB87 & $\begin{array}{l}\text { F: CTGATCTCTGTGCCAGGTACTA } \\
\text { R: GACCAAACTAACATTCTCACGC }\end{array}$ & 2 & $(\mathrm{GA})_{52}$ & $135-150$ & 0.5231 & 0.2500 & 0.3577 & 47 & JN561141 \\
\hline YB88 & $\begin{array}{l}\text { F: CAAAGTTCAGTTGATTACTGGC } \\
\text { R: TAACATTCCTGGTATTGCGAC }\end{array}$ & 2 & $(\mathrm{CA})_{3} \mathrm{~N}_{2}(\mathrm{CA})_{8} \mathrm{~N}_{2}(\mathrm{CA})_{21}$ & $125-140$ & 0.1754 & 0.0000 & 0.1317 & 50.5 & JN561142 \\
\hline
\end{tabular}

$\mathrm{Ta}=$ annealing temperature; $\mathrm{PIC}=$ polymorphism information content.

Seven of the 12 newly developed microsatellite markers were highly polymorphic (PIC $>0.5$ ) and could be useful in further genetic studies on $H$. ovina, such as genetic diversity, pedigree analysis, construction of genetic linkage maps, and marker-assisted selection breeding studies. In addition, the genetic diversity index of $H$. ovina in our study was a slightly lower than those of H. discus (Zhan et al., 2008) and H. diversicolor. This may be due to the overfishing of its wild resources, which could result in small population size and the overexploitation of its natural environment. Furthermore, this result could be related to the samples used to detect the polymorphism of the microsatellite loci and the microsatellite loci used to analyze the genetic diversity of $H$. ovina. Thus, in order to reveal the accurate genetic background of wild $H$. ovina, more sample areas and larger sample sizes should be utilized in future studies.

\section{ACKNOWLEDGMENTS}

Research supported by the Returned Scholars Project of the Ministry of Education of China [(\#2006)331], the Foundation for Innovative Research Team of Jimei University, 
China (\#2010A004), and the Program for New Century Excellent Talents in Fujian Province University [(\#2006)35].

\section{REFERENCES}

Clarke KR and Gorley RN (2001). PRIMER (plymouth routines in multivariate ecological research) v5: user manual/ tutorial. Primer-E Ltd., Plymouth, 1-91.

Evans B, White RW and Elliott NG (2000). Characterization of microsatellite loci in the Australian blacklip abalone (Haliotis rubra, Leach). Mol. Ecol. 9: 1183-1184.

Evans B, Bartlett J, Sweijd N, Cook P, et al. (2004). Loss of genetic variation at microsatellite loci in hatchery produced abalone in Australia (Haliotis rubra) and South Africa (Haliotis midae). Aquaculture 233: 109-127.

Gao AB and Wu DJ (2005). Microsatellite Markers for Paternity Testing of Liangshan Semi-fine Wool Sheep. Hereditas 1: 85-90.

Geiger DL (1999). Distribution and biogeography of the recent Haliotidae (Gastropoda: Vetigastropoda) world-wide. Int. J. Malacol. (Boll. Malacol.) 35: 57-120.

Huang B and Hanna PJ (1998). Identification of three polymorphic microsatellite loci in blacklip abalone, Haliotis rubra (Leach), and detection in other abalone species. J. Shellfish Res. 17: 795-800.

Jarayabhand P and Paphavasit N (1996). A review of the culture of tropical abalone with special reference to Thailand. Aquaculture 140: 159-168.

Klinbunga S, Pripue P, Khamnamtong N, Puanglarp N, et al. (2003). Genetic diversity and molecular markers of the tropical abalone (Haliotis asinina) in Thailand. Mar. Biotechnol. 5: 505-517.

Li Q, Park C and Kijima A (2002). Isolation and characterization of microsatellite loci in the Pacific abalone, Haliotis discus hannai. J. Shellfish Res. 21: 811-816.

Li Q, Park C and Kijima A (2003). Allelic transmission of microsatellites and application to kinship analysis in newly hatched Pacific abalone larvae. Fish Sci. 69: 883-889.

Li Q, Park C, Endo T and Kijima A (2004). Loss of genetic variation at microsatellite loci in hatchery strains of the Pacific abalone (Haliotis discus hannai). Aquaculture 235: 207-222.

Li ZB (2006). The genetic diversity and differentiation of $H$. ovina populations by allozyme analysis. In: 13 th International Congress on Genes. Gene Families and Isozymes - ICGGFI, Shanghai, 201-207.

Li ZB (2009). The genetic diversity and differentiation of Haliotis ovina by AFLP. In: 2009 Conference on Environmental Science and Information Application Technology (ESIAT 2009). IEEE, Wuhan, 206-209.

Li ZB, Appleyard SA and Elliott NG (2006). Population structure of Haliotis rubra from South Australia inferred from nuclear and mtDNA analyses. Acta Oceanol. Sin. 25: 99-112.

Li ZB, Appleyard SA and Elliott NG (2008). Comparative study on MtDNA CO I and CO II gene fragment of Haliotis ovina and H. asinina. Oceanol. Limnol. Sin. 39: 168-173.

Miller KM, Laberee K, Kaukinen KH, Li S, et al. (2001). Development of microsatellite loci in pinto abalone (Haliotis kamtschatkana). Mol. Ecol. Notes 1: 315-317.

Sekino M and Hara M (2001). Microsatellite DNA loci in Pacific abalone Haliotis discus discus (Mollusca, Gastropoda, Haliotidae). Mol. Ecol. Notes 1: 8-10.

Rousset F (2010). Genepop 4.0 for Windows and Linux Manual. [http://kimura.univ-montp2.fr/ rousset/Genepop.pdf].

Selvamani MJP, Degnan SM, Paetkau D and Degnan BM (2000). Highly polymorphic microsatellite loci in the Heron Reef population of the tropical abalone Haliotis asinina. Mol. Ecol. 9: 1184-1186.

Selvamani MJP, Degnan SM and Degnan BM (2001). Microsatellite genotyping of individual abalone larvae: parentage assignment in aquaculture. Mar. Biotechnol. 3: 478-485.

Van Oosterhout C, Hutchinson WF, Wills DPM and Shipley P (2004). MICRO-CHECKER: software for identifying and correcting genotyping errors in microsatellite data. Mol. Ecol. Notes 4: 535-538.

Zhan AB, Bao ZM, Wang ML, Chang D, et al. (2008). Development and characterization of microsatellite markers for the Pacific abalone (Haliotis discus) via EST database mining. J. Ocean Univ. China (English Edition) 7: 219-222. 